Bergersen, F. J. (1954). J. gen. Microbiol. 11, 175-179.

\title{
The Filamentous Forms of Bacillus megaterium
}

\author{
By F. J. BERGERSEN* \\ Department of Bacteriology, University of Otago Medical School, \\ Dunedin, New Zealand
}

SUMMARY: The fine filaments of Bacillus megaterium are shown to arise from large basal cells: they have paired nuclear bodies within walls differing in composition from those of the normal vegetative cells. No evidence was found for any sexual fusion of these filaments.

Young cultures of Bacillus megaterium often contain filamentous forms, especially when grown on blood-containing media. These differ from the vegetative cells typical of the growth cycle described by the author (Bergersen, 1953). DeLamater (1951), and DeLamater \& Hunter (1953), described fusion tubes by means of which a diploid phase was instituted in $B$. megaterium. These tubes were fine filaments which fused with large haploid cells and were supposed to transfer nuclear material from one cell to another. Bisset (1953) criticized this work and stated that the filaments involved were septate, and it was therefore difficult to understand how they could function as fusion tubes. The present work was undertaken as a study of the fine filaments, with particular reference to their cytology and behaviour in living cultures.

\section{MATERIALS AND METHODS}

The bacteria used were strains of Bacillus megaterium isolated in Dunedin and also NCTC strain 7581. These strains were maintained on nutrient agar slopes and subcultured in meat extract broth at $35^{\circ}$ overnight before being used. In all the experiments the inocula were taken from 12 to $18 \mathrm{hr}$. broth cultures. When human serum $(4 \%, v / v)$ was added to a nutrient agar base, copious fine filaments were produced in $3-5 \mathrm{hr}$. at $35^{\circ}$. Filament production was also examined on serum-free media using inocula from serum-free broth and from human blood agar.

Slide cultures were prepared by pouring the melted agar media thinly in Petri dishes: when it had set, the inocula were spread evenly on the surface, care being taken that heavy loop tracks were not left: strips $1.5 \times 0.5 \mathrm{~cm}$. were cut from the agar and mounted on sterile slides under thin coverslips $1.5 \mathrm{~cm}$. square. The preparations were then partially sealed with sterile vaseline: this minimized drying effects, while at the same time an air gap was left on either side of the agar strip to maintain aeration during the time of observation. These slide cultures were observed continuously by means of a phase-contrast microscope mounted in a specially built incubator kept at $35^{\circ}$.

Cytological preparations were made on coverslips from impression films

* Present address : The Microbiology Section, Division of Plant Industry, Commonwealth Scientific and Industrial Research Organisation, Canberra, A.C.T., Australia. 
from agar cultures. These were fixed in osmic acid vapour and stained by the HCl-Giemsa method for nuclear structure. Cell walls were stained by Victoria blue $4 \mathbf{R}$ after treatment with $10 \%$ tannic acid for 10-15 min. The method of Post \& Laudermilk (1942) was adapted as follows for studies of the cell walls of the filaments. Fixed impression films were covered with a solution of iodine $(2 \%)$ in potassium iodide $(5 \%)$ for 10 sec., blotted dry and mounted in saturated aqueous lithium chloride solution.

\section{OBSERVATIONS}

Slide cultures. In these cultures the origin and growth of the fine filaments were carefully followed in a large number of developing microcolonies. When the inocula were taken from 12 to $18 \mathrm{hr}$. broth cultures, the sequence of developments was as follows. During the first hour the usual lag-phase enlargement of the bacteria proceeded and the first one or two divisions occurred. The cells which produced the filaments then enlarged slightly to form a basal cell and a tapering extension was produced at one end. The basal cell became divided from the developing filament; which after $2-3 \mathrm{hr}$. was sometimes 3 times the length of the parent cell, but more often was long and tenuous, often becoming lost among other bacilli of the growing colony. At first the filaments showed no sign of division, but after $3 \mathrm{hr}$. some fragmentation occurred at the basal end. Often the parent cell divided several times before producing the filament, and on several occasions one of the resulting cells divided with two septa very close together and a very small cell resulted (Pl. 1, figs. 1, 2). Some of the filaments suddenly lost contrast after 2-3 hr. and remained as 'ghosts' with very little structure. Most of them, however, retained their contrast until they became overgrown and lost, but the filaments were always paler than the actively dividing vegetative cells. As they extended, the fine filaments grew between the cells of the growing microcolonies often twisting and coiling and otherwise showing considerable flexibility. The tips of many of them came to rest against the walls of large cells and seemed to stick to them. This was at first thought to be a fusion of the filament and the large cell. After further examination this seemed doubtful since an apparently fused filament often would break away and stick to a cell on the other side (Pl. 1, figs. 1, 2). On one or two occasions the appearance of a fusion was more convincing but there was difficulty in distinguishing fusion from mere contact, in phase-contrast studies.

Both slide cultures and cultures grown on agar plates showed that a basal nutrient agar medium plus human serum $(4 \%, v / v)$ gave many fine filaments during the first $4 \mathrm{hr}$. of incubation. A few were seen on the basal medium without serum, but these were small and often lysed. When the inoculum was taken from blood agar cultures and then grown on the basal medium more filaments were produced. It seems clear that these forms are therefore produced as the result of a nutritional stimulus as previously reported by DeLamater (1951) for fusion tubes. Slight differences in the extent to which filaments were formed were observed in the various strains studied, but growth and behaviour seemed uniform. 
Nuclear stains. These preparations showed that the filaments contained pairs of nuclear bodies throughout their length. Sometimes a septum divided the terminal part. The basal cells had a complex arrangement of nuclear material, stained blue by Giemsa, and also a number of pink granules resembling the metabolically active granules described as growing points (Bergersen, 1953) in vegetative cells. These granules confuse the black and white photomicrographs in Pl. 1, but the generalized lay-out of nuclear
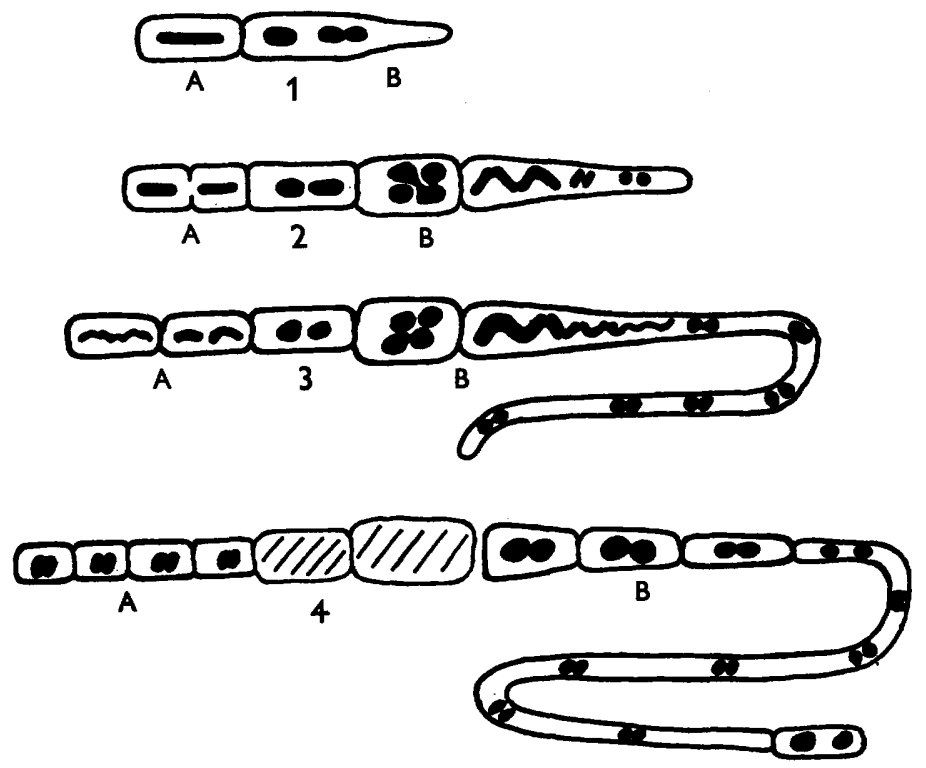

Fig. 1. A diagrammatic representation of the formation of fine filaments, $\mathbf{B}$, and the corresponding stages of vegetative growth A. 1, the first stage; 2 , the basal cell divided from the filament; 3, zigzag nuclear material producing pairs of nuclear bodies in the filament; 4 , septation of the filament begins.

material is shown in the diagram (Fig. 1). This complex nuclear apparatus was most noticeable in basal cells whose filaments were still attached or divided by only one septum. Older filaments became completely separated from the basal cells which often lysed. The thick proximal end of the filaments contained a bar of nuclear material composed of a zigzag of poorly defined bars from which the paired bodies seemed to be derived.

Cell-wall stains. Victoria blue $4 R$ stained preparations showed the filaments to be mainly non-septate, although the basal cells and beginning of the filament were divided in older cultures (Pl. 2, figs. 9-12). With Post \& Laudermilk's stain photographs of organisms were unsuitable for reproduction, but direct visual examination was satisfactory. The cell walls of large vegetative organisms stained a brownish yellow, typical of certain types of cellulose, but the walls of the fine filaments remained unstained. This suggests a different chemical structure in the walls of these forms. 


\section{DISCUSSION}

From these studies it seems that the fine filaments of Bacillus megaterium are cell types produced in response to a nutritional stimulus provided by a factor in human serum; this is in agreement with DeLamater(1953). They are produced from enlarged basal cells whose nuclear material seems to undergo considerable rearrangement. The filaments themselves have paired nuclear bodies, whereas previous work has shown that vegetative filaments have a fusion nucleus which breaks up to form the nuclei of separate cells; these may continue in the vegetative cycle (Bergersen, 1953) or in some groups proceed to spore formation (Kleinberger-Nobel, 1945). The lack of cellulose-like material in the cell wall may explain the flexibility of the fine filaments, which is often considerable. It is the opinion of the present author that these fine filaments are those described by DeLamater \& Hunter (1953) as fusion tubes. Evidence was sought during the present work to support the hypothesis of DeLamater \& Hunter that these forms may be concerned in a sexual phase in B. megaterium. In slide culture apparent fusion between filaments and large cells was seen, without however any evidence from the cytological preparations for any dissolution of the cell walls between apparently fusing elements ( $\mathrm{Pl}$. 2, figs. 10, 11). It cannot be said at this stage that true fusion did not occur; but it was not observed during the present work although slide cultures were continuously observed for long periods and although large numbers of cytological preparations were made and each one exhaustively studied. Some bacilli were seen with short filaments resembling DeLamater's photographs of 'fusion tubes'. From the present work it appears clear that these were the beginnings of filament formation and not the result of fusion (Pl. 1, figs. 5-8). The true function of the fine filaments in cultures on agar media is obscure but no evidence was found for a sexual fusion between filament and large bacillus.

\section{REFERENCES}

Bergersen, F. J. (1953). A probable growth cycle in Bacillus megaterium. J. gen. Microbiol. 9, 26.

Bisset, K. A. (1953). Do bacteria have mitotic spindles, fusion tubes and mitochondria? J. gen. Microbiol. 8, 50.

De Lamater, E. D. (1951). A new cytological basis for bacterial genetics. Cold. Spr. Harb. Symp. quant. Biol. 16, 381.

DeLamater, E. D. \& Hunter, E. H. (1953). Conditions controlling secondary colony formation in B. megaterium. J. Bact. 65, 739 .

KuIENEBERGER-NobeL, E. (1945). Changes in the nuclear structure of bacteria. J. Hyg., Camb. 44, 99.

Post, E. E. \& Laudermilk, J. D. (1942). An iodine stain for cellulose. Stain Tech. $17,21$. 
Journal of General Microbiology, Vol. 11, No. 2
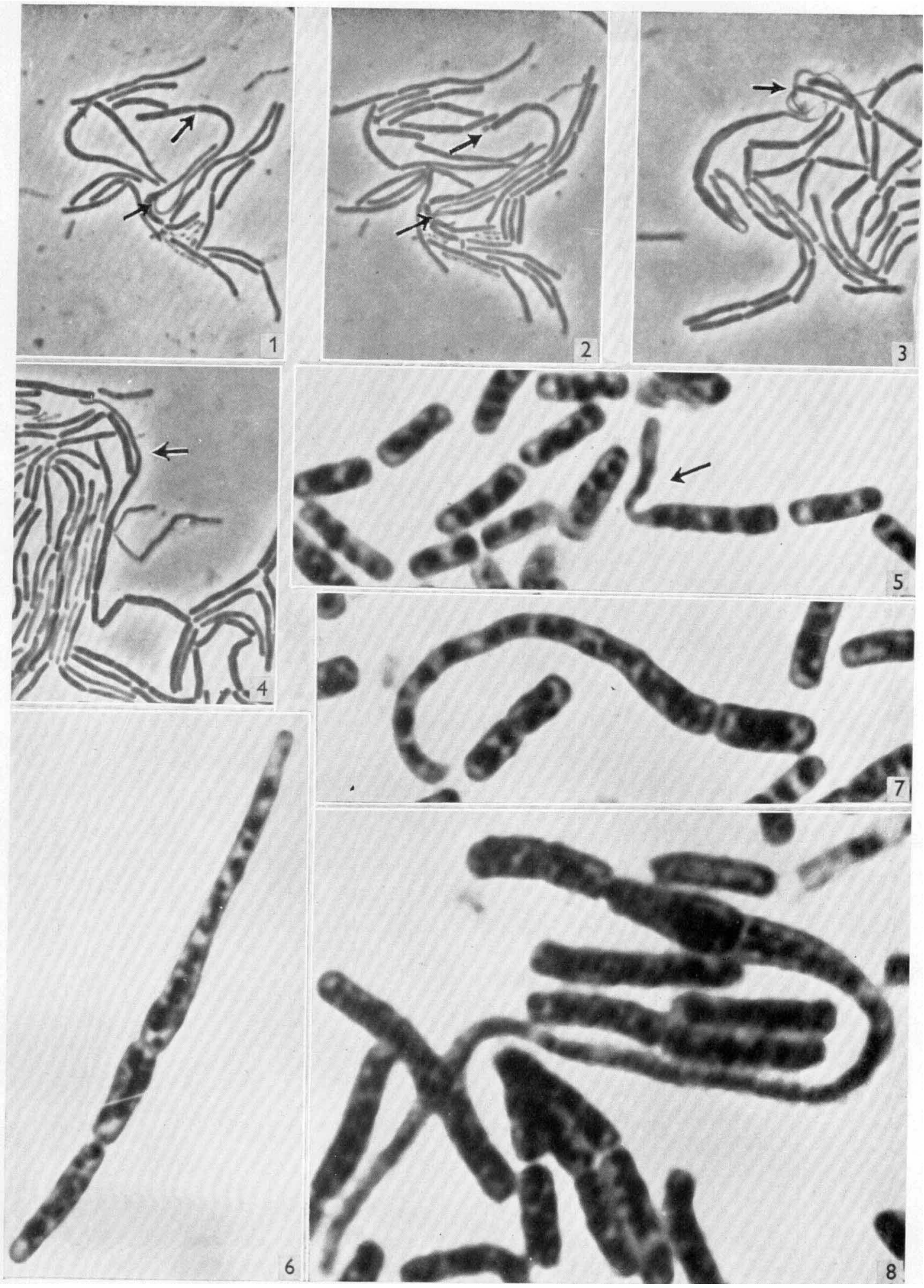

F. J. Bergersen-Filamentous forms of Bacillus megaterium. Plate 1 
Journal of General Microbiology, Vol. 11, No. 2

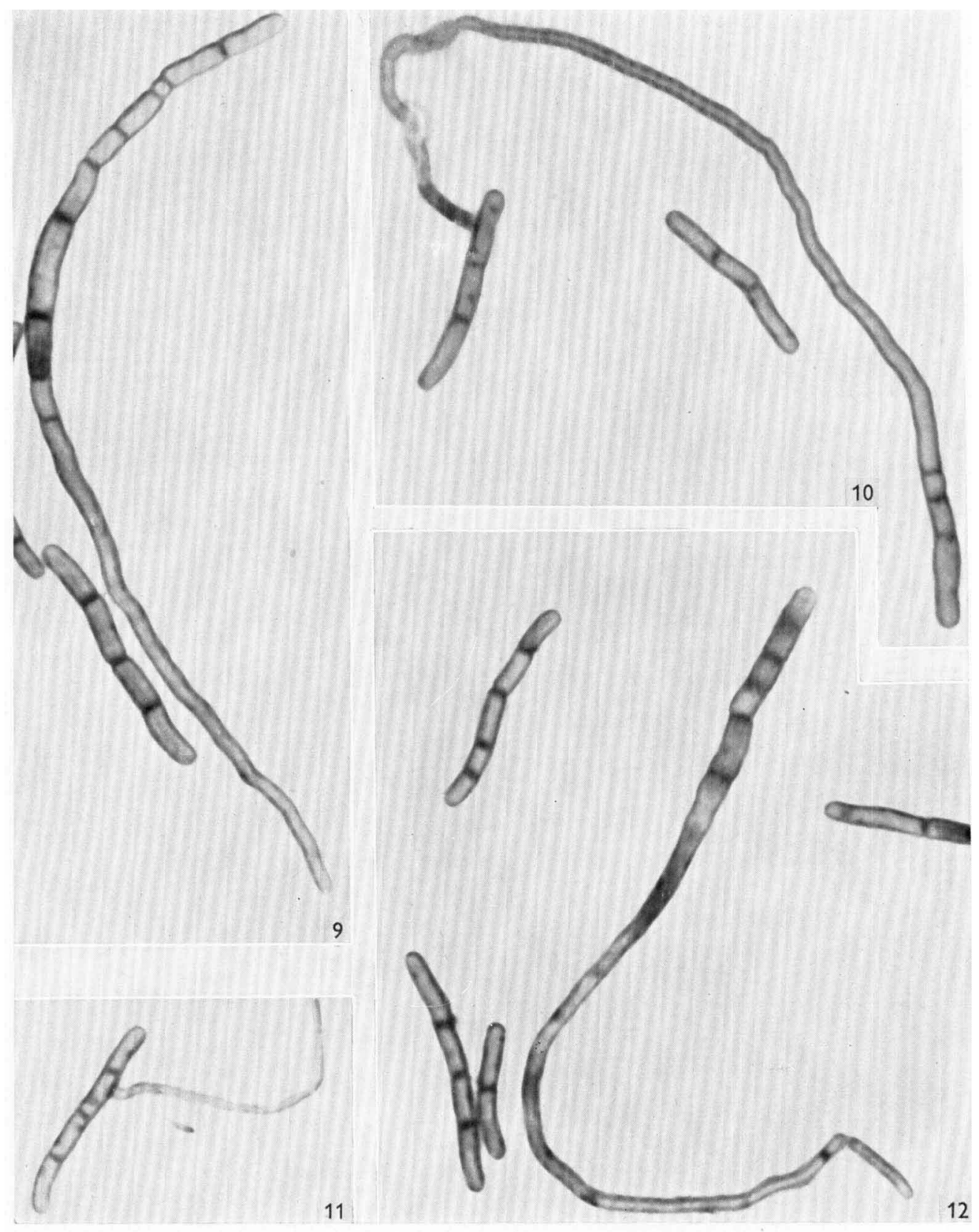

F. J. Bergersen--Filamentuds horms of Bacilles megaterium. Piate 2 


\section{EXPLANATION OF PLATES}

Prate 1

Figs. 1, 2. Two photographs of the same field taken 15 min. apart. The upper arrow shows the formation of a very small cell and the lower arrow shows an apparently fusing filament which becomes stuck to another cell on the opposite side. Phase contrast. $\times 450$.

Fig. 3. A much coiled, flexible filament. Phase contrast. $\times 450$.

Fig. 4. A typical fine filament and its large basal cells.

Fig. 5. The beginning of filament formation. A stage resembling 'fusion tubes'. HClGiemsa. $\times 3500$.

Figs. 6-8. Later stages than fig. 5: swelling basal cells and paired nuclear bodies in the filament HCl-Giemsa. $\times 3500$.

Prate 2

Victoria Blue $4 \mathbf{R}$ stained impression smears. $\times 2000$.

Fig. 9. Non-septate filament, basal cell and vegetative cells.

Figs. 10, 11. Apparently fusing filament and large cell. No dissolution of cell wall.

Fig. 12. Filament with septate tip and basal cells.

(Received 13 February 1954) 